\title{
OTONOMI DAERAH DAN PELUANG INVESTASI UNTUK PERCEPATAN PEMBANGUNAN
}

\author{
Bambang Sugianto, Dita Kurniawati, Zakaria Abbas \\ Dosen Sekolah Tinggi Ilmu Hukum Sumpah Pemuda \\ Mahasiswa Program Doktor Ilmu Hukum Universitas Sriwijaya \\ bambangsugianto1969@gmail.com
}

\begin{abstract}
Abstrak
Tujuan Otonomi daerah memberikan kemudahan daerah dalam melaksanakan kewenangan, sehingga dalam menjalankan kewenangan membawak efek positif dalam berinvestasi. Investasi bertujuan untuk peningkatan ekonomi masyarakat daerah serta peningkatan Pendapatan Daerah, tetapi otonomi sering disalahgunakan oleh Pemerintah daerah terutama yang berhubungan dengan perizinan, sehingga Investor mengalami kesulitan dan hambatan. Tujuan otonomi daerah supaya ada dampak positif serta memberi pelayan publik lebih mudah dan cepat, penyederhanaan Pelayanan Kegiatan Investasi, dan penyederhanaan (regulasi) pelayanan kegiatan ekonomi membantu kelancaran usaha dari para pelaku ekonomi, karena deregulasi dipandang untuk meningkatkan efisiensi bagi pelaku ekonomi. Adanya kepastian proses adminitrasi dan kepastian hukum yang dapat menjamin keamanan dan stabilitas politik Daerah, singkronisasi regulasi antar pemerintah daerah dengan pemerintah pusat, Daerah harus membuka diri dan mempermudah perizinan sektor investasi terutama berhubungan rekruitmen tenaga kerja yang besar, terukurnya kemampuan keuangan daerah dalam era otonomi daerah dengan menggunakan kinerja fiscal sehingga tercapainya keberhasilan daerah dalam menjalani otonomi daerah.
\end{abstract}

\section{Kata Kunci: Otonomi Daerah, Investasi.}

\begin{abstract}
In doing investment, there are often problems, one of which is regional autonomy, the challenges of implementing investment in Indonesia in the era of regional autonomy in Indonesia. In its regulation, there is a system of division of authority in facilitating the entry of investments with the investment arrangements at the regional level referring to investment regulations at the national level. Therefore, although the direction of Indonesian economy after Regional Autonomy refers to the economy in the region, it must be remembered that the authority of regional autonomy towards regional independence remains within the framework of the unitary state. The direction of the investment policy and the increase in business activities through investment policies are expected to create opportunities for the growth and development of the business world for every large, medium, and small scale of economic actor. Simplification of Investment Services, Simplification (deregulation) economic activity services helps accelerate the operation of economic actors, because deregulation is seen to increase efficiency for economic actors. The certainty of the administrative process and legal certainty that can guarantee the security and political stability of the region, synchronization of regulations between the local government and the central government, faster in licensing and the realization of certainty, the regional government must open up and facilitate licensing of the investment sector, especially related to the large recruitment of workers, measurable regional
\end{abstract}


financial capacity in the era of regional autonomy by using performance so that the regional achievement can successfully undergone the regional autonomy.

\section{Keywords: Regional Autonomy, Investment.}

\section{A.Pendahuluan}

Perkembangan dan pertumbuhan investasi di-erah otonomi daerah, merupakan salah satu indikator kemajuan dan partumbuhan ekonomi di Indonesia. Investasi yang dilakukan secara umum bertujuan untuk dapat mendukung peningkatan dan memajukan kesejahteraan masyarakat Indonesia, sesuai dengan tujuan Negara Republik Indonesia. Investasi pada hakekatnya memang berlangsung di daerah, sebab daerah mempunyai kewilayahan secara administratif pemerintahan. ${ }^{1}$

Dalam berinvestasi sering mengalami permasalah, salah satunya adalah otonomi daerah, tantangan pelaksanaan investasi di Indonesia era otonomi daerah di Indonesia dimulai pada Tahun 2001 semenjak berlakunya UU Nomor 22 Tahun 1999 tentang Pemerintah Daerah dan kemudian diperbaharui dengan UU Nomor 23 Tahun 2014 tentang Pemerintahan Daerah, makna penting pengaturan tersebut adalah bahwa ada sistem pembagian kewenangan dalam mempermudah masuknya investasi. Kekayaan sumber daya alam yang sangat melimpah di Indonesia merupakan potensi sangat besar yang dapat dikembangkan, termasuk melalui Investasi Langsung. Kekayaan bahan tambang serta hasil bumi Indonesia sangat fleksibel untuk investasi yang berbasis sumber daya alam (resource based investment) ${ }^{2}$

Otonomi daerah sendiri, sebagai suatu konsep yang dituangkan di dalam UndangUndang Nomor 23 Tahun 2014 serta mengalami perubahan melalui Undang-Undang Republik Indonesia Nomor 2 Tahun 2015

${ }^{1}$ Santoso Sembiring, Hukum Investasi, kedua (Bandung: Nusa Aulia, 2010), 155.

${ }^{2}$ Fery Dona, "Peran Penanaman Modal Asing ( PMA ) Dalam Pembangunan Ekonomi Di Era Otonomi Daerah," Al- Ahkam Jurnal Ilmu Syari,Ah Dan Hukum 2, no. 1 (2017): 80-90. dan Undang-Undang Republik Indonesia Nomor 9 Tahun 2015 tentang Perubahan Kedua Atas UndangUndang Nomor 23 Tahun 2014 tentang Pemerintahan Daerah bertujuan untuk mempermudah serta memberikan peluang besar bagi Pemerintahan Dearah dalam meningkatkan pertumbuhan ekonomi melalui investasi, apakah itu investasi dalam negeri dan investasi asing.

Pasal 33 Undang-Undang Dasar (UUD) 1945 mengamanatkan bahwa bumi, air dan kekayaan alam yang terkandung di dalamnya dikuasai oleh negara dan dipergunakan sebesar-besar untuk kemakmuran rakyat. Amanat UUD 1945 ini merupakan landasan pembangunan pertambangan dan energi untuk memanfaatkan potensi kekayaan sumberdaya alam mineral dan energi yang dimiliki secara optimal dalam mendukung pembangunan nasional yang berkelanjutan. $^{3}$

Pemanfaatan dan pengelolaan Sumber Daya Alam terbatas oleh negara diperlukan melibatkan pihak ketiga dalam hal ini investor untuk mengelolah kekayaan alam sehingga memberi nilai tambah secara nyata bagi perekonomian nasional dalam usaha mencapai kemakmuran dan kesejahteraan rakyat secara berkeadilan, ${ }^{4}$ Untuk mewujudkan tujuan sebagaimana diamanatkan itu pemerintah menerbitkan Undang Undang Nomor 25 Tahun 2007 tentang Penanaman Modal. yang bertujuan untuk mempermudah dan meningkatnya ber-investasi sering

\footnotetext{
${ }^{3}$ Negara Republik Indonesia, “UndangUndang Dasar Republik Indonesia 1945" (1945), https://www.hukumonline.com/pusatdata/detail/lt4ca 2eb6dd2834/node/lt49c8ba3665987/uud-undangundang-dasar-1945.

${ }^{4}$ Surizki Febrianto, "Iklim Investasi Penanaman Modal Dalam Dunia Pertambangan Di Indonesia Investment Climate Of Mining Business In Indonesia," Jurnal IUS Kajian Hukum Dan Keadilan 6, no. 3 (2018): 444-55.
} 
mengalami kendala dan hambatan, terjadinya hambatan adalah dalam koordinasi antara pemerintah Kabupaten dan Provinsi dalam menerbitkan regulasi. Di dalam Penjelasan Umum UU Nomor 25 Tahun 2007 dinyatakan pentingnya peranan pemerintah daerah. Pemerintah diharuskan untuk menjalin koordinasi yang baik antara pemerintah pusat dan pemerintah daerah. ${ }^{5}$

Koordinasi tersebut harus dijalankan dengan semangat otonomi daerah. Dalam pengembangan peluang bagi potensi daerah saling berkoordinasi menjadi titik penting bagi penanaman modal (investasi) di daerah, baik dalam urusan kepemerintahan terkait investasi, maupun dalam kerangka kemampuan daerah untuk melakukan investtasi. Hal ini justru menjadi kontraproduktif karena menambah beban publik (masyarakat) dan juga menghambat masuknya investtasi ke daerah. Masyarakat tidak memberikan kontribusi seperti yang diharapkan (melalui pembayaran retribusi dan pajak daerah), dan hal ini bisa jadi disebabkan masih rendahnya kemampuan membayar (ability to pay) ataupun kemauan membayar pajak (willingness to pay) masyarakat. Salah satu faktor yang diyakini menjadi penyebab masih rendahnya kedua hal ini (kemampuan dan kemauan untuk membayar) adalah tidak adanya perubahan kesejahteraan masyarakat yang signifikan. ${ }^{6}$

Ada beragam pilihan yang dimiliki pemerintah untuk memperbaiki iklim penanaman modal di daerah, dimana salah satu kebijakan yang terkait dengan kepentingan tersebut, adalah penerapan sistem Pelayanan Terpadu Satu Pintu (PTSP) yang didasarkan pada UU Nomor 25 Tahun 2007 tentang Penanaman Modal. Kebijakan ini

\footnotetext{
${ }^{5}$ Negara Republik Indonesia, "UndangUndang Republik Indonesia Nomor 25 Tahun 2007 Tentang Penanaman Modal" (2007).

${ }^{6}$ Priyo Hari Adi, "Kemampuan Keuangan Daerah Dalam Era Otonomi Dan Relevansinya Dengan Pertumbuhan Ekonomi (Studi Pada Kabupaten Dan Kota Se Jawa - Bali).," Artikel Yang Dipresentasikan Dalam The Accounting Conference Yang Diselenggarakan Departemen Akuntansi Fakultas Ekonomi, 2007, 2-17.
}

sangat menarik untuk dicermati, karena jika ditilik pada substansinya, memiliki kemiripan dengan KeputusanPresiden Nomor 29 Tahun 2004 tentang Penyelenggaraan Penanaman Modal dalam rangka PMA dan PMDN melalui Sistem Pelayanan Satu Atap. Keppres ini pernah dianggap pemerintah daerah sebagai upaya pemerintah pusat untuk menarik kembali kewenangan penanaman modal yang pernah didesentralisasikan. Di sisi lain, secara teoritik, PTSP dapat meningkatkan kualitas pelayanan perizinan dalam bidang investasi, melalui penyederhanaan perizinan dan percepatan waktu penyelesaian ${ }^{7}$

PTSP merupakan salah satu upaya daerah untuk dapat memberikan kemudahan dalam mengadakan investasi. PTSP tersebut pada umumnya, oleh pemerintah daerah diakomodasi dalam bentuk peraturan-peraturan daerah. Peraturan daerah tentang PTSP akan memberikan jaminan kepastian hukum bagi para investor untuk memperkirakan dan merancang persiapan investasinya sendiri. Selain itu, PTSP dapat membuat investor yakin bahwa investasi dapat dilakukan dengan perlindungan hukum. Selain melalui perda, dapat ditemukan juga aturanaturan tentang PTSP yang dijadikan acuan.

Beberapa kebijakan acuan dalam penyelenggaraan pelayanan administrasi penanaman modal di daerah, antara lain meliputi Keputusan Presiden Nomor 97 Tahun 1993 tentang Tatacara Penanaman Modal sebagaimana telah diubah dengan Keputusan Presiden Nomor 115 Tahun 1998 jo. Keputusan Presiden Nomor 117 Tahun 1999, Keputusan Meninves/Kepala BKPM Nomor 38/SK/1999 tentang Pedoman dan Tatacara Permohonan Penanaman Modal yang didirikan dalam rangka PMA dan PMDN, dan Keputusan Presiden Nomor 29 Tahun 2004 tentang Penyelenggaraan Penanaman Modal

${ }^{7}$ Asropi, Strategi Perbaikan Iklim Investasi Di Daerah, Dalam Bunga Rampai Administrasi Publik: Dimensi Pelayanan Publik Dan Tantangannya Dalam Administrasi Negara (Publik) Di Indonesia. (Jakarta: Lembaga Administrasi Negara, 2007), 2. 
dalam rangka PMA dan PMDN Melalui Sistem Pelayanan Satu Atap.

Kejelasan peraturan tersebut, untuk menarik investor, dapat dilakukan pula peningkatan sumber pendanaan dan ketepatan alokasi investasi pembangunan melalui penciptaan iklim kondusif untuk pengembangan usaha dan penciptaan lapangan kerja, serta mengembangkan pemberdayaan masyarakat dan kemitraan dalam proses pembangunan dengan mengimplementasikan paradigma masyarakat membangun. Hal ini diwujudkan dengan memberikan peluang pengurusan syarat investasi yang ketat namun mudah, melakukan pendekatan secara baik dengan calon investor, serta kemampuan pemerintah daerah dalam memberikan dorongan kepada masyarakat untuk terbuka dalam hal potensi sosial budayanya.

Oleh Karena itu penulis melihat dengan otonomi daerah diperlukan adanya singkronisasi regulasi sehingga investasi akan mudah masuk kedaerah dan dapat memberi kontribusi dalam pembangunan. Dan jangan sampai otonomi daerah itu akan menghambat dan mempersulit berinvestasi sehingga kekayaan Sumber Daya Alam tidak dapat dikelolah dengan baik dan bermanfaat untuk takyat. Di sinilah sebenarnya kelayakan regulasi pendukung investasi dapat dilihat dari dua sisi, yaitu regulasi Pusat/ atau Provinsi dan regulasi pemerintah daerah. Dua hal utamanya dapat dilihat sebagai berikut. Pertama, peraturan/ atau regulasi pendukung investasi di daerah. Misalnya, bahwa perlu adanya perubahan mengenai regulasi mengenai ketenagakerjaan. keimigrasian, kepabeanan, pajak dan retribusi, lingkungan hidup sampai dengan regulasi tentang kontribusi dan kompensasi yang pada umumnya regulasi-regulasi tersebut belum mendukung investasi. Kedua, kewenangan pemberian ijin untuk melakukan investasi seharusnya dapat mendukung, terutama yang terkait dengan good governance. Pemerintah daerah diharapkan dapat bersikap dengan lebih baik kepada para calon investor. Terutama dengan kesedia- annya untuk memberikan pelayanan yang jujur dan terbuka melalui PTSP.

\section{B.Dinamika Investasi, Otonomi Daerah Dan Kebijakan Investasi}

Sejalan dengan kebijakan otonomi daerah, adalah pelimpahan kewenangan dari pemerintah pusat kepada pemerintah daerah yang merupakan daerah otonom untuk mengatur dan mengurus masyarakatnya menurut kehendaknya sendiri berdasarkan aspirasi masyarakat, sesuai dengan peraturan perundang-undangan yang berlaku di bawah Negara Kesatuan Republik Indonesia. Di sisi kepentingan pemerintah pusat, otonomi daerah ditujukan untuk mewujudkan kesejahteraan bidang ekonomi, pendidikan politik, pelatihan kepemimpinan, menciptakan stabilitas politik, dan mewujudkan demokratisasi sistem pemerintahan di daerah, sedangkan pada sisi kepentingan pemerintah daerah otonomi daerah ditujukan untuk :

1. Mewujudkan political equality, artinya melalui otonomi daerah diharapkan akan lebih membuka kesempatan bagi masyarakat untuk berpartisipasi dalam

Berbagai aktivitas politik di tingkat lokal atau daerah

2. Untuk menciptakan local accountability, artinya dengan otonomi daerah diharapkan mampu meningkatkan per- tanggungjawaban pemerintah dalam mensejahterakan masyarakat daerah.

3. Untuk mewujudkan local responsiveness, artinya dengan otonomi daerah diharapkan akan mempermudah antisipasi terhadap berbagai masalah yang muncul dan sekaligus meningkatkan akselerasi pembangunan sosial dan ekonomi daerah. $^{8}$

\footnotetext{
${ }^{8}$ Suryo Pratolo, "Peran Otonomi Daerah Untuk Meningkatkan Fungsi Pengelolaan Keuangan Daerah Sebagai Instrumen Manajemen Dalam Kebijakan Alokasi Belanja Pelayanan Publik," Jurnal Akuntansi Dan Investasi 12, no. 1 (2011): 36-59.
} 
Otonomi ini bertujuan untuk mengatur pemerintahannya terutama dalam menggali sumber-sumber pendapatan asli daerahnya serta dalam memajukan partumbuhan ekonomi daerahnya, termasuk dalam menciptakan iklim investasi yang kondusif di daerahnya. Dengan bekal kebijakan desentralisasi tersebut setiap daerah mempunyai wewenang penuh dalam menciptakan iklim investasi yang kondusif sehingga memungkinkan tercapainya tujuan-tujuan pembangunan. Investasi yang akan masuk ke suatu daerah bergantung kepada daya saing investasiyang dimiliki oleh daerah yang bersangkutan. Daya saing investasi suatu daerah tidak terjadi dengan serta merta. Pembentukan daya saing investasi, berlangsung secara terus-menerus dari waktu ke waktu dan dipengaruhi oleh banyak faktor.

Keberhasilan daerah untuk meningkatkan daya saing terhadap investasi salah satunya bergantung kepada kemampuan daerah dalam merumuskan kebijakan yang berkaitan dengan investasi dan dunia usaha. Investasi. Tujuan investasi dilihat dari berbagai kepentingan, yakni antara kepentingan investor dengan kepentingan pemerintah, yang mana antara kedua kepentingan tersebut jika dilihat dari motivasi dan tujuan yang ingin dicapai akan jelas berbeda antara satu dan lainnya. Dari sisi pemerintah mengharapkan dengan adanya investasi akan memberikan sumbangan yang tidak kecil artinya bagi kegiatan pembangunan yang pada gilirannya akan dapat menwujudkan kesejahteraan rakyat. Sementara disisi lain, investor melakukan investasi lebih banyak didasarkan kepada pertimbangan dan orientasi yang bersifat ekonomis. ${ }^{9}$

\section{C.Penanaman Modal dan Keuangan Daerah}

Dalam konteks pemerintahan daerah, penyelenggaraan fungsi pemerintahan daerah akan terlaksana secara optimal apabila penyelenggaraan urusan pemerintahan di-

\footnotetext{
${ }^{9}$ Sumantoro, Pengantar Tentang Pasar Modal Di Indonesia, Jakarta (Jakarta: Ghalia Indonesia, 2004), 15.
}

ikuti dengan pemberian sumber-sumber penerimaan yang cukup pada daerah, dengan mengacu pada UU Nomor 33 Tahun 2004 tentang Perimbangan Keuangan antara Pemerintah Pusat dan Pemerintah Daerah. Besarannya disesuaikan dengan pembagian kewenangan antara pemerintah pusat dan pemerintah daerah. Hal ini berarti bahwa semua sumber keuangan yang melekat pada setiap urusan pemerintah yang diserahkan kepada daerah, menjadi sumber keuangan daerah. ${ }^{10}$ Dalam rangka otonomi daerah ini pula, pemerintahan daerah memiliki kewenangan lebih banyak dalam mengurus dan mengelola anggaran daerahnya (AP$\mathrm{BD})$.

Pengaturan investasi pada tingkat daerah mengacu pada peraturan investasi di tingkat nasional. Hal ini dilakukan mengingat walaupun arah perekonomian Indonesia paska Otonomi Daerah mengacu pada ekonomi di daerah, namun harus diingat bahwa kewenangan otonomi daerah yang menuju kemandirian daerah tetap berada dalam kerangka negara kesatuan, sehingga tidak dapat diartikan adanya kebebasan penuh secara absolut dari suatu daerah untuk menjalankan hak dan fungsi otonomi menurut kehendak daerah tanpa mempertimbangkan kepentingan nasional. Arah Kebijakan Investasia dan peningkatan kegiatan dunia usaha melalui kebijakan investasi diharapkan dapat menciptakan peluang bagi tumbuh dan berkembangnya dunia usaha bagi setiap pelaku ekonomi skala besar, menengah, kecil. Selain itu sangat relevan dalam mewujudkan pemerataan terhadap akses-akses dan sumber-sumber ekonomi. Penyederhanaan Pelayanan Kegiatan Investasi Penyederhanaan (deregulasi) pelayanan kegiatan ekonomi membantu kelancaran usaha dari para pelaku ekonomi, karena deregulasi dipandang sebagai salah satu cara

\footnotetext{
${ }^{10}$ Nurlan Darise, Pengelolaan Keuangan
} Daerah, kedua (Jakarta: PT. Indeks Jakarta, 2006), 21. 
untuk meningkatkan efisiensi bagi para pelaku ekonomi. ${ }^{11}$

Berkaitan dengan kegiatan investasi baik dalam negeri ataupun asing, pemerintah telah mengambil langkah-langkah deregulasi pelayanan investasi melalui beberapa paket kebijakan yang tidak lain bertujuan untuk menarik minat investor agar mau menanamkan modal. Sejalan dengan pelaksanaan otonomi daerah, pemerintah secara terus menerus melakukan penyempurnaan berkaitan dengan penyederhanaan pelayanan kegiatan investasi, yang tidak lain bertujuan untuk memberikan kemudahan bagi para calon investor dalam melakukan kegiatan investasinya. Dalam menarik ivestasi antaralain: sumber daya alam yang melimpah, jumlah penduduk yang besar, tenaga kerja yang relative murah. Berbagai langkah kebijakan yang telah di ambil oleh pemerintah dalam upaya menarik minat para investor, baik di dalam maupun luar negeri agar mau berinvestasi di Indonesia yaitu dengan program Omnibus Law.

Strategi Kebijakan Investasia baik jangka pendek dan berhubungan dengan kebijakan investasi, beberapa langkah dan strategi sangat perlu dipertimbangkan sebagai skala prioritas dalam investasi nasional. Dalam hal ini pemerintah antara lain harus mengaktifkan asset produksi yang belum didayagunakan yang masih mempunyai prospek disehatkan untuk meningkatkan produksi. Selain itu perlu didorong investasi pada bidang usaha yang mengutamakan sumber daya domistik yang berorientasi ekspor dengan mempunyai kaitan dengan pengadaan sembilan bahan pokok, mempunyai sifat padat karya, dan cepat menghasilkan serta memberikan efek kepada penyehatan pembayaran luar negeri. Dalam jangka pendek langkah yang harus dilakukan adalah pengembangan industry padat karya, seperti produksi tekstil, electronika, industry kerajinan dan sejenisnya. Upaya pengembangan industry ini perlu

${ }^{11}$ Rudini, Otonomi Daerah Peluang Dan Tantangan (Jakarta: Pustaka Sinar Harapan, 2001), 45 . dilakukan mengingat industri ini banyak menyerap tenaga kerja dan sekaligus dapat mengurangi tingkat pengangguran dan selama ini telah berkembang dengan cukup baik serta memberikan sumbangan yang tidak kecil pada perolehan devisa. Selain itu perbaikan dalam intensif kebijakan investasi perlu dilakukan mencakup pemberian layanan administrasi dan layanan bisnis yang efisien.

Kemudian pengadaan program-program pengembangan sumber daya manusia terutama difokuskan pada peningkatan kualitas sumberdaya manusia dan peningkatan koordinasi lintas sektoral dan fasilitator bagi investor dalam kegiatan investasi. Strategi Jangka Menengah beberapa langkah dan strategi yang dapat dilakukan melalui pentahapan priorotas investasi berdasarkan sektor pengembangan priorotas investasi berdasarkan kondisi daerah, pengembangan prioritas investasi berdasarkan institusi, serta peningkatan kerjasama internasional di bidang investasi dalam rangka menarik investor secara selektif dan terarah. Dalam jangka menengah langkah dan strategi yang perlu dilakukan adalah pengembangan industri yang berbasis sumber daya alam, khususnya agri industry.

Upaya ini perlu dilakukan untuk mengurangi ketergantungan pada bahan baku impor, dengan demikian perolehan devisa dari hasil ekspor dapat dimanfaatkan seoptimal mungkin dan sekaligus dapat menghemat devisa.

Strategi Jangka Panjang adapun, langkahlangkah yang perlu dilakukan berkaitan dengan kebijakan investasi di Indonesia adalah pengembangan industry yang berbasis teknologi dan pengetahuan (knowledge based industry) secara bertahap. Upaya ini perlu dilakukan untuk mendapat nilai tambah yang tinggi melalui proses teknologi secara bertahap dengan mempertimbangkan tingkat teknologi yang ada. Selain itu, langkah yang perlu dilakukan adalah deregulasi dan debirokratisasi dalam kegiatan investasi dan perdagangan. Terkait dengan hal itu, kesiapan daerah menjadi 
faktor penting yang cukup menentukan keberhasilan daerah dalam mengimplementasi kebijakan otonomi daerah ini. Salah satu indikator yang bisa digunakan adalah kemampuan keuangan daerah. Kemampuan keuangan daerah dalam era otonomi daerah sering diukur dengan menggunakan kinerja PAD. Serta keberhasilan daerah dalam menjalani otonomi daerah. Pajak dan Retribusi daerah (yang merupakan komponen penyumbang PAD terbesar) seyogyanya mampu membiayai belanja pemerintah daerah. $^{12}$

\section{D.Kesimpulan}

Dari uraian diatas dan dapat ditarik suatu kesimpulan daerah dapat dikatakan mandiri dan layak untuk dijadikan daerah yang pro-investasi, yaitu:

1. Adanya kepastian dalam proses adminitrasi dan kepastian hukum yang dapat menjamin keamanan dan stabilitas politik Daerah;

2. Adanya singkronisasi regulasi antar pemerintah daerah dengan pemerintah pusat yang berhubungan dengan investtasi, sehingga lebih cepat dalam perizinan dan terwujudnya sebuah kepastian;

3. Pemerintah daerah harus membuka diri dan mempermudah perizinan sektor investasi terutama yang berhubungan recuritmen tenaga kerja yang besar.

4. Terukurnya kemampuan keuangan daerah, dalam era otonomi daerah dengan menggunakan kinerja PAD sehingga tercapainya keberhasilan daerah dalam menjalani otonomi daerah.

${ }^{\mathbf{1 2}}$ Priyo Hari Adi, "Kemampuan
Keuangan Daerah Dalam Era Otonomi Dan
Relevansinya Dengan Pertumbuhan Ekonomi
(Studi Pada Kabupaten Dan Kota Se Jawa -
Bali)."

\section{DAFTAR PUSTAKA}

Asropi. Strategi Perbaikan Iklim Investasi Di Daerah, Dalam Bunga Rampai Administrasi Publik: Dimensi Pelayanan Publik Dan Tantangannya Dalam Administrasi Negara (Publik) Di Indonesia. Jakarta: Lembaga Administrasi Negara, 2007.

Febrianto, Surizki. "Iklim Investasi Penanaman Modal Dalam Dunia Pertambangan Di Indonesia Investment Climate Of Mining Business In Indonesia." Jurnal IUS Kajian Hukum Dan Keadilan 6, no. 3 (2018): 444-55.

Fery Dona. "Peran Penanaman Modal Asing ( PMA ) Dalam Pembangunan Ekonomi Di Era Otonomi Daerah." Al- Ahkam Jurnal Ilmu Syari,Ah Dan Hukum 2, no. 1 (2017): $80-90$.

Negara Republik Indonesia. Undang-Undang Dasar Republik Indonesia 1945 (1945). https://www.hukumonline.com/pusatdata/detail/lt4ca2eb6dd2834/node/lt49c8ba3665 987/uud-undang-undang-dasar-1945. Modal (2007).

Nurlan Darise. Pengelolaan Keuangan Daerah. Kedua. Jakarta: PT. Indeks Jakarta, 2006.

Priyo Hari Adi. "Kemampuan Keuangan Daerah Dalam Era Otonomi Dan Relevansinya Dengan Pertumbuhan Ekonomi (Studi Pada Kabupaten Dan Kota Se Jawa - Bali).” Artikel Yang Dipresentasikan Dalam The Accounting Conference Yang Diselenggarakan Departemen Akuntansi Fakultas Ekonomi, 2007, 2-17.

Rudini. Otonomi Daerah Peluang Dan Tantangan. Jakarta: Pustaka Sinar Harapan, 2001.

Santoso Sembiring. Hukum Investasi. Kedua. Bandung: Nusa Aulia, 2010. 
Sumantoro. Pengantar Tentang Pasar Modal Di Indonesia, Jakarta. Jakarta: Ghalia Indonesia, 2004.

Suryo Pratolo. "Peran Otonomi Daerah Untuk Meningkatkan Fungsi Pengelolaan Keuangan Daerah Sebagai Instrumen Manajemen Dalam Kebijakan Alokasi Belanja Pelayanan Publik.” Jurnal Akuntansi Dan Investasi 12, no. 1 (2011): 36-59. 
